\title{
Evidence for Dietary Niche Separation Based on Infraorbital Foramen Size Variation among Subfossil Lemurs
}

\author{
Magdalena N. Muchlinski ${ }^{a, b} \quad$ Laurie R. Godfrey ${ }^{c}$ \\ Kathleen M. Muldoon d, e Lydia Tongasoa ${ }^{f}$ \\ a Department of Anatomy and Neurobiology, University of Kentucky, College of Medicine, \\ Lexington, Ky., ${ }^{b}$ Department of Anatomy and Pathology, Marshall University, Joan C. \\ Edwards School of Medicine, Huntington, W. Va., ' Department of Anthropology, University \\ of Massachusetts, Amherst, Mass., 'Department of Anatomy, Dartmouth Medical School, \\ and ${ }^{\text {eDepartment }}$ of Anthropology, Dartmouth College, Hanover, N.H., USA; \\ fDépartement de Paléontologie et d'Anthropologie Biologique, Université d'Antananarivo, \\ Antananarivo, Madagascar
}

\section{Key Words}

Infraorbital foramen area $\cdot$ Subfossil lemurs $\cdot$ Paleoecology $\cdot$ Madagascar $\cdot$ Diet

\begin{abstract}
The size of the infraorbital foramen (IOF) has been used in drawing both phylogenetic and ecological inferences regarding fossil taxa. Within the order Primates, frugivores have relatively larger IOFs than folivores or insectivores. This study uses relative IOF size in lemurs to test prior trophic inferences for subfossil lemurs and to explore the pattern of variation within and across lemur families. The IOFs of individuals belonging to 12 extinct lemur species were measured and compared to those of extant Malagasy strepsirhines. Observations matched expectations drawn from more traditional approaches (e.g. dental morphology and microwear, stable isotope analysis) remarkably well. We confirm that extinct lemurs belonging to the families Megaladapidae and Palaeopropithecidae were predominantly folivorous and that species belonging to the genus Pachylemur (Lemuridae) were frugivores. Very high values for relative IOF area in Archaeolemur support frugivory but are also consistent with omnivory, as certain omnivores use facial touch cues while feeding. These results provide additional evidence that the IOF can be used as an informative osteological feature in both phylogenetic and paleoecological interpretations of the fossil record.

Copyright $\odot 2011$ S. Karger AG, Basel
\end{abstract}

\begin{tabular}{|c|c|}
\hline RGER & $\begin{array}{l}\text { (c) 2011 S. Karger AG, Basel } \\
0015-5713 / 10 / 0816-0330 \$ 26.00 / 0\end{array}$ \\
\hline $\begin{array}{l}\text { Fax +4161306 } 1234 \\
\text { E-Mail karger@karger.ch } \\
\text { www.karger.com }\end{array}$ & $\begin{array}{l}\text { Accessible online at: } \\
\text { www.karger.com/fpr }\end{array}$ \\
\hline
\end{tabular}

Magdalena N. Muchlinski, Department of Anatomy and Neurobiology, University of Kentucky, College of Medicine, MN210 Chandler Medical Center Lexington, KY 40536 (USA)

Tel. +1 859323 1770, Fax +1 8593235946 E-Mail magdalena.muchlinski@uky.edu 


\section{Introduction}

The infraorbital foramen (IOF) is located below the inferior margin of the orbit, and transmits the infraorbital nerve (ION) to specialized mechanoreceptors (Pacinian corpuscles, Merkel's disks, and Ruffini corpuscles) associated with the rhinarium, vibrissae (whiskers), and upper lip [Ebara et al., 2002]. The IOF transmits the afferent sensory ION to specialized mechanoreceptors that respond to mechanical stimuli such as tension, pressure, vibration, and displacement [Brecht et al., 1997; Marshall et al., 2006]. Some of these receptors can be found around the vibrissa shaft [Ebara et al., 2002], but others can be found in the upper lip and surrounding maxillary region. The sensory acuity of an anatomical region (e.g. finger tips, palm of hand, lips) correlates with the number of receptors located within a specific region [Kandel et al., 2000; Oelschlager and Oelschlager, 2002; Marino, 2007]. Generally, as the number of receptors associated with a particular anatomical region increases, more nerve innervation (and thus a thicker nerve) is required to transmit the sensory information detected by receptors to the brain [Jonas et al., 1992; Mackinnon and Dellon, 1995; Cull et al., 2003]. Furthermore, nerve area is a reliable estimate of total nerve axon count, as examples from total optic [Jonas et al., 1992; Cull et al., 2003] and hypoglossal [Mackinnon and Dellon, 1995] nerve area show. Mackinnon and Dellon [1995] documented variation in axon densities across an individual nerve, but when total axon count across nerve samples was calculated within a single taxon, they noted that axon count correlated with nerve area. Thus, the relative size of the ION should reflect mechanoreceptive sensory acuity (or touch sensitivity) of the maxillary region. Muchlinski [2008] showed that ION cross-sectional area accounts for $85-90 \%$ of the variance in IOF cross-sectional area across a broad selection of mammals. In terms of vascular structures, there is only a relatively small artery that passes through the IOF and no vein is present [Muchlinski, 2008]. Furthermore, IOF and ION cross-sectional area scale isometrically $(\ln I O N=-0.2+1.0 \times$ $\ln I O F)$, thus IOF area can be used as a proxy for maxillary mechanoreception in fossils for which nerve size cannot be measured directly.

However, a more refined interpretation of IOF size variation must take into account that mammals use their snouts to explore their environment in different ways. Primates, unlike most other mammals, have relatively small IOFs [Muchlinski, 2010b], which indicates that primates depend less on 'face touch' (maxillary mechanoreception) than most other mammals - most likely a correlate of transferring touch discrimination to the fingers. Nevertheless, facial tactile exploration is important in some primate species. An animal's reliance on maxillary mechanoreception can be affected by its activity pattern (e.g. nocturnality or use of low light conditions [Klages et al., 2002]) or by its preferred substrate (arboreality [Ahl, 1986, 1987]; aquatic/subterranean [Baron et al., 1990]). Among primates, Muchlinski [2010a] established diet as the best predictor of variation in relative IOF size. In particular, relative IOF area distinguishes primate species feeding primarily on leaves or insects (with relatively small IOF areas) from those feeding primarily on fruit (with relatively large IOF areas). Interestingly, Baron et al. [1990] found a similar pattern between the volume of the trigeminal brainstem complex (both sensory and motor) and diet among both primates and soricids. They found that the trigeminal brainstem in folivorous species was smaller than in more frugivorous and insectivorous species. One implication of these findings is that folivores may depend less on max- 
illary mechanoreception in food acquisition and processing than do insectivores and frugivores [Baron et al., 1990; Muchlinski, 2010a].

Food selection among primates involves, first, searching out and identifying food, and then contacting and evaluating the food [Dominy, 2004]. Primates locate foods using visual, auditory, and olfactory cues [Dominy et al., 2001]. Insect and leaf evaluation do involve some degree of maxillary mechanoreception [Lucas, 1994; Dominy et al., 2001], but most evaluation occurs in the postcanine oral cavity [Ungar, 2002]. Fruit selection and evaluation are distinct from insect and leaf assessment; in the former, fruit testing depends more heavily on rostral sensory cues [Lucas, 1994; Ungar, 1998; Dominy et al., 2001; Dominy, 2004]. Hands play an important role in evaluating fruit texture, but the premaxillary region is also critical for fruit inspection [Dominy, 2004]. Once a fruit is identified, primates are reported to inspect it haptically with their digits, lips, and incisors, which are all mechanically sensitive [Peleg, 1980]. For example, Eulemur rubriventer uses its hands to pull terminal branches with fruit clusters toward its face, whereupon it uses its mouth and lip to evaluate the fruit before selecting and ingesting certain ones [Tecot, 2008]. Many primates bite and taste fruit to determine the stage of maturity of a fruit, because color does not provide a clear indication of fruit edibility [Dominy et al., 2001]. Among anthropoid primates, frugivores have broader and more spatulate incisors than either insectivores or folivores, apparently because husking fruit requires more incisal preparation than either leaf or insect consumption [Ungar, 1998]. High maxillary mechanoreception (and, consequently, larger IOFs) may be an adaptation for fruit selection and evaluation [Muchlinski, 2010a]. Nobody has evaluated how maxillary mechanoreception of omnivorous primates compares with that of primate frugivores, folivores, and insectivores. Although most primates can be described as omnivorous, few are omnivores par excellence, and many of these (e.g. Daubentonia madagascariensis, Cheirogaleus spp.) can be found on the island of Madagascar.

In this study, we examined, first, whether extant and extinct lemurs show similar distributions in relative IOF area, and whether the relative IOF area differences observed in frugivorous and folivorous extant primates as documented by Muchlinski [2010a] hold for extant lemurs. We then examined variation in relative IOF area within frugivorous lemurs to see whether finer dietary groups could be distinguished, and to verify the utility of our metric in post hoc dietary predictions. Finally, we applied our metric to extinct lemurs to assess the probabilities of dietary group membership, and to determine whether dietary inferences drawn for extinct lemurs on the basis of relative IOF area match prior trophic assessments. If agreement can be demonstrated, results of this study would not merely bolster prior trophic assessments of subfossil lemur species, but they would support the broad utility of IOF area as a tool for dietary inference in extinct primates [Muchlinski, 2010a].

\section{Materials and Methods}

We measured the IOFs on 101 skulls belonging to 16 extant Malagasy strepsirhine species in 5 families (table 1). In addition, we measured the IOFs of 30 skulls of individuals belonging to 12 extinct lemur species in the following 4 families: Megaladapidae ( 2 species), Lemuridae ( 2 species), Archaeolemuridae (3 species), and Palaeopropithecidae (5 species) (table 1). 
Table 1. Species sample sizes, means, and standard deviations for IOF and molar areas

\begin{tabular}{|c|c|c|c|c|c|}
\hline & $\mathrm{n}$ & $\begin{array}{l}\text { IOF area } \\
\mathrm{mm}^{2}\end{array}$ & $\mathrm{SD}$ & $\begin{array}{l}\text { Molar area } \\
\mathrm{mm}^{2}\end{array}$ & $\mathrm{SD}$ \\
\hline \multicolumn{6}{|l|}{ Cheirogaleidae } \\
\hline Cheirogaleus major & 2 & 1.49 & 0.31 & 11.08 & 0.32 \\
\hline Cheirogaleus medius & 4 & 1.01 & 0.08 & 8.16 & 0.61 \\
\hline Microcebus murinus & 8 & 0.57 & 0.14 & 4.53 & 0.96 \\
\hline Mirza coquereli & 1 & 1.15 & - & 6.52 & - \\
\hline \multicolumn{6}{|l|}{ Daubentoniidae } \\
\hline Daubentonia madagascariensis & 4 & 2.58 & 0.43 & 16.39 & 0.30 \\
\hline \multicolumn{6}{|l|}{ Indriidae } \\
\hline Avahi laniger & 6 & 0.54 & 0.24 & 19.20 & 0.10 \\
\hline Indri indri & 5 & 1.06 & 0.31 & 42.73 & 1.10 \\
\hline Propithecus edwardsi & 4 & 1.00 & 0.39 & 34.26 & 1.31 \\
\hline Propithecus verreauxi & 10 & 1.83 & 0.70 & 41.50 & 2.52 \\
\hline \multicolumn{6}{|l|}{ Archaeolemuridae } \\
\hline Archaeolemur edwardsi ${ }^{\dagger}$ & 3 & 12.16 & 2.08 & 74.94 & 12.97 \\
\hline Archaeolemur majori ${ }^{\dagger}$ & 8 & 8.78 & 2.00 & 65.02 & 6.90 \\
\hline Archaeolemur sp. cf. A. edwardsi ${ }^{\dagger}$ & 3 & 13.41 & 1.43 & 78.68 & 0.89 \\
\hline \multicolumn{6}{|l|}{ Palaeopropithecidae } \\
\hline Archaeoindris fontoynontii ${ }^{\dagger}$ & 1 & 8.56 & - & 366.86 & - \\
\hline Mesopropithecus globiceps ${ }^{\dagger}$ & 2 & 2.38 & 1.66 & 50.72 & 8.60 \\
\hline Babakotia radofilai ${ }^{\dagger}$ & 1 & 2.21 & - & 68.40 & - \\
\hline Palaeopropithecus kelyus ${ }^{\dagger}$ & 1 & 4.69 & - & 194.18 & - \\
\hline Palaeopropithecus maximus ${ }^{\dagger}$ & 1 & 8.45 & - & 232.40 & - \\
\hline \multicolumn{6}{|l|}{ Lemuridae } \\
\hline Eulemur fulvus & 10 & 1.68 & 0.65 & 44.49 & 2.61 \\
\hline Eulemur macaco & 10 & 2.27 & 0.70 & 37.76 & 3.01 \\
\hline Eulemur rubriventer & 5 & 1.54 & 0.56 & 43.55 & 1.75 \\
\hline Hapalemur griseus & 7 & 0.83 & 0.13 & 25.02 & 1.18 \\
\hline Lemur catta & 9 & 1.32 & 0.48 & 38.01 & 2.17 \\
\hline Varecia variegata & 10 & 2.76 & 0.90 & 52.95 & 4.19 \\
\hline Pachylemur insignis ${ }^{\dagger}$ & 4 & 5.74 & 2.16 & 72.98 & 8.99 \\
\hline Pachylemur jullyi ${ }^{\dagger}$ & 1 & 5.99 & - & 75.33 & - \\
\hline \multicolumn{6}{|l|}{ Megaladapidae } \\
\hline Megaladapis edwardsi ${ }^{\dagger}$ & 1 & 12.49 & - & 490.00 & - \\
\hline Megaladapis madagascariensis ${ }^{\dagger}$ & 4 & 5.18 & 2.11 & 267.86 & 42.90 \\
\hline \multicolumn{6}{|l|}{ Lepilemuridae } \\
\hline Lepilemur mustelinus & 6 & 0.52 & 0.04 & 14.71 & 0.21 \\
\hline
\end{tabular}

Molds were created of the IOF outlet using a flexible and injectable molding material. These molds were sectioned and photographed under a stereomicroscope. From these images, IOF area (in $\mathrm{mm}^{2}$ ) was calculated using Scion Image ${ }^{\circledR}$ software (for details see Muchlinski [2010a]).

Among larger more diverse samples, IOF area is positively correlated with body mass ( $\mathrm{p}<$ 0.001) [Muchlinski, 2010a, b], and thus IOF area must be size adjusted before comparisons of

Subfossil Lemur Diets and Infraorbital Foramen

$\overline{\text { Folia Primatol 2010;81:330-345 }}$ 
species varying greatly in body size can be made. IOF area does correlate, albeit weakly, with body mass $(\mathrm{p}=0.05)$ among the living strepsirhines in our sample. In our living strepsirhine sample, body mass ranges between 0.09 and $6.5 \mathrm{~kg}$. This narrow body mass distribution can partially account for the poor correlation between body mass and IOF area. When the larger subfossil taxa were included in our analysis, we found that IOF area is significantly correlated with body mass ( $\mathrm{p}<0.0001)$. Based on these findings, IOF area must be size adjusted because larger animals have larger foramina than smaller animals.

To make such an adjustment, we used upper second molar area ('molar area' - i.e., the product of the tooth's maximum mesiodistal and buccolingual diameters) as a measure of size, and calculated the ratio of IOF to molar area for each individual. Size-adjusted IOFs for any given animal is then $\ln (\mathrm{IOF}$ area/molar area). Although molar area is often a poor indicator of body mass [Hylander, 1985; Jungers, 1990], it was selected for use here for several reasons. First, molar area measurements were available for each specimen for which IOF area was measured. Secondly, molar area is generally better correlated with body mass than are other cranial measurements, such as skull length [Muchlinski, 2002]. For our sample of 16 extant lemur species, the correlation (Pearson's $\mathrm{r}$ ) for species means for ln molar area and $\ln$ body mass is 0.89 ( $\mathrm{p}<$ 0.001). A reduced major axis regression of $\ln$ molar area on $\ln$ body mass for our extant lemur species indicates that molar area scales with slightly negative allometry, but the confidence intervals include isometry (In molar area $=2.94+0.61$ ln body mass; $\mathrm{CI}=0.45-0.81)$. A leastsquares regression yields similar results (ln molar area $=2.95+0.58 \ln$ body mass; $\mathrm{CI}=0.50$ 0.67). Ideally, in order to use molar area measurements to correct for variation in body size in extinct lemurs, we should be able to demonstrate isometric scaling for the relationship between molar area and body size across all lemurs. Of course, we cannot measure body mass in extinct lemurs; however, we can estimate their body masses using postcranial measurements, which correlate better than cranial measurements with body mass in extant mammals and indeed in lemurs [Jungers et al., 2008]. A reduced major axis regression of $\ln$ molar area on $\ln$ body mass for our 28 extinct and extant lemur species indicates that molar area scales with slightly negative allometry, but the confidence intervals include isometry ( $\ln$ molar area $=3.05+0.57 \ln$ body mass; $\mathrm{CI}=0.43-0.73$ ). A least-squares regression yields similar results ( $\ln$ molar area $=3.12+$ $0.54 \ln$ body mass; $\mathrm{CI}=0.39-0.67)$. Within our sample, we find that molar area is within the confidence limits for geometric similarity or isometric scaling (slope $=0.67$ ), which suggests it is an appropriate surrogate for body mass for this sample.

For each extant lemur sampled, we assessed diet using the relevant literature. Each species was first placed in 1 of 2 categories, predominantly folivorous or predominantly frugivorous, on the basis of the percentage of fruit eaten (with fruit defined as any reproductive part of plants, following Muchlinski [2010a]). Kay [1973] suggests that primates with 45\% fruit in their diet should be classified as frugivores. We used a more conservative value of $\geq 60 \%$. We grouped taxa as frugivores if $\geq 60 \%$ of their diet is fruit; if not, taxa were grouped as either folivores or omnivores based on whether the non-fruit portion of the diet was primarily leaves or a combination of food items. Because in Madagascar the protein content of fruit is low [Ganzhorn et al., 2009], Malagasy frugivores must derive their protein from foliage, animals or exudates. Those species for which animal matter is a significant proportion of the diet tend to consume little or no foliage, but exudates may be important dietary components. We therefore subdivided lemur 'frugivores' into 2 groups depending on the degree to which they supplement fruit with foliage versus some combination of animals and exudates (table 2). Our dietary groups effectively reflect variation in the relative amount of foliage in diets, from significant (folivorous) to moderate (frugivorous-folivorous) to little (frugivorous-omnivorous).

Because closely related species are more likely to share ecological and anatomical characteristics than distantly related species, we incorporated phylogenetic information into our analyses. Phylogenetically independent contrasts were calculated using the PDAP:PD-TREE module [Midford et al., 2005] of Mesquite version 2.72 [Maddison and Maddison, 2009]. The phylogenetic branching sequence used here is provided in figure 1. The phylogeny we used reflects the topology for the major clades of extant strepsirhines generated by Horvath et al. [2008] as well as information on sister taxon relationships drawn from the most comprehensive molecular analysis of extinct lemurs [Orlando et al., 2008]. All branch lengths were set to 
Table 2. Dietary assessment of extant lemurs, with sources

\begin{tabular}{|c|c|c|}
\hline Family and species & Diet & Notes and sources \\
\hline \multicolumn{3}{|l|}{ Cheirogaleidae } \\
\hline Cheirogaleus major & $\mathrm{OM}$ & $\begin{array}{l}\text { Fruit, flowers, nectar, animals [Wright and Martin, 1995; } \\
\text { Lahann, 2007; Muldoon and Goodman, 2010] }\end{array}$ \\
\hline Cheirogaleus medius & $\mathrm{OM}$ & $\begin{array}{l}\text { Fruit, nectar, flowers, animals [Hladik et al., 1980; Fietz and } \\
\text { Ganzhorn, 1999; Lahann, 2007] }\end{array}$ \\
\hline Microcebus murinus & $\mathrm{OM}$ & $\begin{array}{l}\text { Fruit, arthropods, gums, insect secretions, small vertebrates } \\
\text { [Radespiel et al., 2006; Lahann, 2007; Dammhahn and Kappeler, } \\
\text { 2008] }\end{array}$ \\
\hline Mirza coquereli & $\mathrm{OM}$ & $\begin{array}{l}\text { Fruit, flowers, gums, insect secretions, insects [Hladik et al., } \\
\text { 1980; Pages, 1980; Muldoon and Goodman, 2010] }\end{array}$ \\
\hline \multicolumn{3}{|l|}{ Daubentoniidae } \\
\hline Daubentonia madagascariensis & $\mathrm{OM}$ & $\begin{array}{l}\text { Fruit, nut kernels, nectar, ants, beetle larvae, termites, earwigs } \\
\text { [Sterling, 1994; Lhota et al., 2008] }\end{array}$ \\
\hline \multicolumn{3}{|l|}{ Indriidae } \\
\hline Avahi laniger & FL & $\begin{array}{l}\text { Leaves, buds, twigs [Ganzhorn et al., 1985; Harcourt, 1991; } \\
\text { Faulkner and Lehman, 2006] }\end{array}$ \\
\hline Indri indri & FL & Young leaves, fruit, flowers and seeds [Powzyck, 1998] \\
\hline Propithecus edwardsi & FL & Leaves, seeds, fruit [Hemingway, 1998; Powzyck, 1998] \\
\hline Propithecus verreauxi & FL & $\begin{array}{l}\text { Leaves, wood, bark stems, fruit, flowers [Richard, 1974; Richard, } \\
\text { 1978; Sailer et al., 1985; Yamashita, 2002; Simmen et al., 2003] }\end{array}$ \\
\hline \multicolumn{3}{|l|}{ Lemuridae } \\
\hline Eulemur fulvus & FL & $\begin{array}{l}\text { Leaves, wood, bark, stems, fruit, some insects [Sussman, 1974; } \\
\text { Gerson, 2000; Vasey, 2000] }\end{array}$ \\
\hline Eulemur macaco & FR & $\begin{array}{l}\text { Fruit, leaves, some insects, flowers, nectar [Colquhoun, 1997; } \\
\text { Andrews and Birkinshaw, 1998; Birkinshaw and Colquhoun, } \\
\text { 1998] }\end{array}$ \\
\hline Eulemur rubriventer & FR & $\begin{array}{l}\text { Fruit, some leaves, insects, flowers [Overdorff, 1996; Tecot, } \\
\text { 2008] }\end{array}$ \\
\hline Hapalemur griseus & FL & Bamboo, leaves, fruit [Grassi, 2006] \\
\hline Lemur catta & FL & $\begin{array}{l}\text { Leaves, wood, bark, stems, fruit, some insects [Sussman, 1974; } \\
\text { Sailer et al., 1985; Sauther, 1991; Yamashita, 2002; Simmen et al., } \\
\text { 2003] }\end{array}$ \\
\hline Varecia variegata & FR & Mainly fruit [Morland, 1992; Balko, 1998; Ratsimbazafy, 2002] \\
\hline \multicolumn{3}{|l|}{ Lepilemuridae } \\
\hline Lepilemur mustelinus & $\mathrm{FL}$ & $\begin{array}{l}\text { Mainly leaves, some wood, bark, stems, fruit and flowers } \\
\text { [Richard, 1987; Lehman, 2007] }\end{array}$ \\
\hline
\end{tabular}

1 for this analysis. Contrasts were uncorrelated with contrast standard deviations [Garland et al., 1999].

Our first task was to compare relative IOF area in extinct and extant Malagasy lemurs using t tests, with and without incorporating phylogenetic information. We did this to check the utility of extant lemurs as a comparative database; if the values for extinct lemurs differ significantly from those for extant lemurs (particularly if they fall outside the extant lemur range), then we would be poorly justified in using extant lemur values in diagnosing diets of extinct lemurs. Next, to verify that relative IOF area reflects diet in extant lemurs, we tested the significance of differences among our 3 dietary groups, again with and without incorporating phylogenetic information. We then examined the relative IOF area scores for extinct lemurs, using their Mahalanobis distances from the 3 extant lemur dietary group centroids to classify 


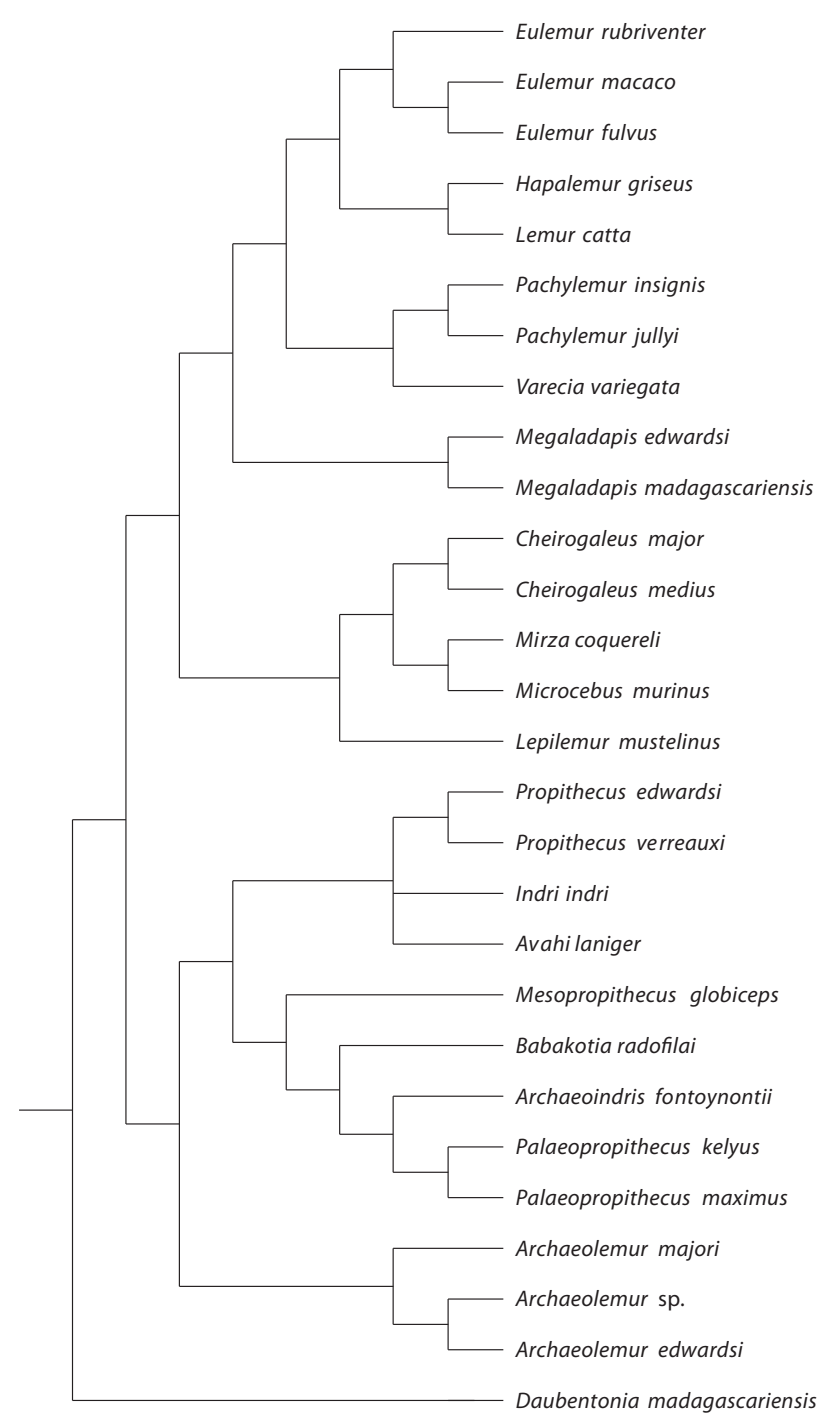

Fig. 1. Phylogenetic branching sequence used for the taxa in this study.

each species. Finally, a univariate discriminant function analysis (SPSS v. 14) was used to derive posterior probabilities of membership in the closest dietary group. The mathematical justification for using DFA for this task is equivalent to that for any algorithm that maximizes one sum of squares relative to another, such as classification trees or cluster analysis using Ward's metric (see Fisher [1925, chapt 49] for the classic explication). Fisher [1925] demonstrated that the 
Fig. 2. A box-and-whisker plot illustrating the distributions of relative IOF area in extant and extinct Malagasy lemurs. There is no significant difference between these 2 groups.

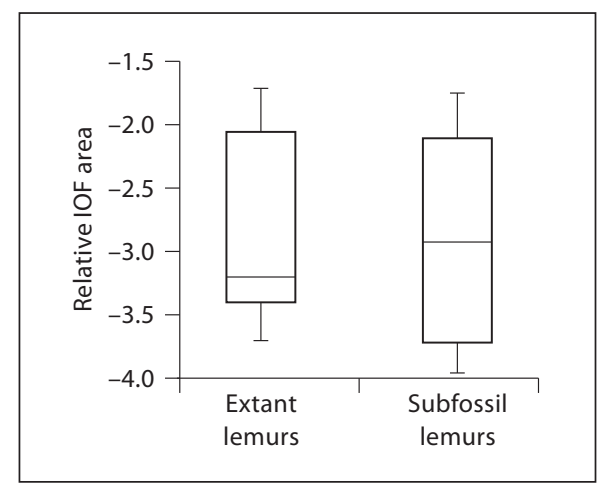

ANOVA/regression framework enables researchers to create or form optimal groups (maximally separated on some metric - originally Euclidean) using any number of dimensions. Finally, we compared dietary predictions derived in such a manner to prior dietary assessments made using other techniques.

\section{Results}

We found no significant difference in the means of relative IOF area for extant and extinct Malagasy lemurs $(t=-0.28$, d.f. $=26, p=0.78$; fig. 2$)$. These results hold when variation in relative IOF area is corrected for phylogenetic relatedness $(t=0.66$, d.f. $=26, p=0.52$ ), and suggest that extant lemurs yield an appropriate comparative database.

Relative IOF area differs significantly in extant Malagasy lemur frugivores and folivores $(\mathrm{t}=4.12$, d.f. $=5.8, \mathrm{p}=0.01)$, with folivores having significantly smaller IOFs. These results hold when phylogenetic information is considered in the analysis $(\mathrm{t}=3.52$, d.f. $=14, \mathrm{p}<0.001)$. Within the group initially identified as extant lemur frugivores, species supplementing fruit primarily with foliage have significantly smaller IOFs than do more omnivorous species. A 3-group ANOVA confirms a strong dietary signal $(\mathrm{F}=91.0$, d.f. $=2.13, \mathrm{p}<0.001)$. Tukey's post hoc tests of honestly significant differences reveal all pairs to differ significantly $(p=0.03$ for folivores vs. frugivore-folivores, $\mathrm{p}<0.001$ for folivores vs. frugivore-omnivores, and $p<0.001$ for frugivore-folivores vs. frugivore-omnivores). The biggest differences were between folivores and frugivore-omnivores (fig. 3a). Results do not differ for relationships between phylogenetic contrasts in relative IOF scores and diet $(p=0.05$ for folivores vs. frugivore-folivores, $\mathrm{p}<0.001$ for folivores vs. frugivore-omnivores, and $\mathrm{p}=0.02$ for frugivore-folivores vs. frugivore-omnivores). Centroid values (with standard deviations) for extant lemur dietary groups are $-3.41 \pm 0.18$ (folivores), $-3.04 \pm 0.27$ (frugivore-folivores), and $-1.95 \pm 0.15$ (frugivore-omnivores).

Table 3 presents mean Mahalanobis distances from each of the 3 group centroids for each extinct lemur species. The smallest distances (suggesting most likely diet) are given in bold; these are also the predicted groups derived by univariate discriminant function analysis (and pictorially represented in figure $3 \mathrm{~b}$ ). The extant 


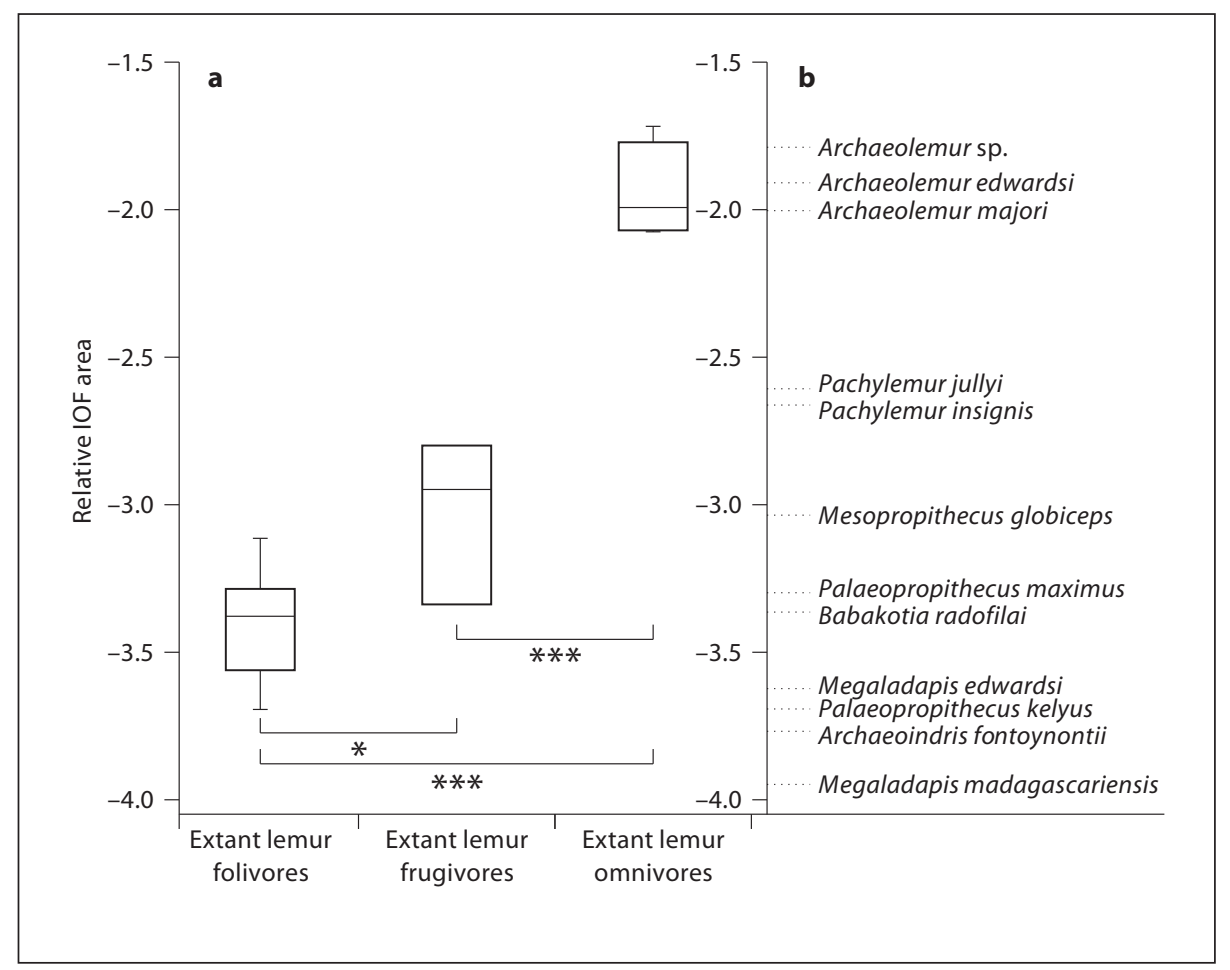

Fig. 3. a Box-and-whisker plot illustrating differences among extant lemur members of the 3 diet groups $\left({ }^{*} \mathrm{p}<0.05{ }^{* * *} \mathrm{p}<0.0001\right)$. $\mathbf{b}$ The IOF area values for subfossils.

species post hoc classification success of the discriminant function analysis was $87.5 \%$. Errors of dietary classification were limited to 1 lemurid species (E. rubriventer) classified by us as a frugivore but predicted to be a folivore, and 1 indriid species (Propithecus verreauxi) classified by us as a folivore but predicted to be a frugivore. No omnivores were misclassified by the discriminant function.

Posterior probabilities for extinct lemur membership in their 'most likely' dietary groups are provided in table 4, which also compares our results to those of prior studies. The general agreement is clear. Archaeolemur edwardsi, Archaeolemur major, and Archaeolemur sp. cf. A. edwardsi fall conspicuously within the frugivoreomnivore distribution. Pachylemur jullyi and Pachylemur insignis fall in the middle of the extant lemur frugivore-folivore distribution. Mesopropithecus globiceps also lies within the frugivore-folivore distribution. Palaeopropithecus maximus, Babakotia radofilai, Megaladapis edwardsi, and Palaeopropithecus kelyus all have significantly lower relative IOF scores than all extant Malagasy lemur frugivores and resemble stricter extant lemur folivores. Archaeoindris fontoynontii and Megaladapis madagascariensis fall below the extant lemur folivore distribution, with very small relative IOF sizes, suggesting little reliance on facial touch sensitivity, and a high percentage of foliage in their diets. 
Table 3. Mahalanobis distances to extant lemur dietary group centroids

\begin{tabular}{lllc}
\hline \multirow{2}{*}{ Species } & \multicolumn{2}{l}{ Mahalanobis distance to } \\
\cline { 2 - 4 } & FL centroid & FR-FL centroid & FR-OM centroid \\
\hline Archaeolemur edwardsi & 8.77 & 4.43 & $\mathbf{0 . 8 6}$ \\
Archaeolemur majori & 7.76 & 3.76 & $\mathbf{0 . 3 4}$ \\
Archaeolemur sp. cf. A. edwardsi & 9.04 & 4.61 & $\mathbf{1 . 1 8}$ \\
Archaeoindris fontoynontii & $\mathbf{1 . 8 9}$ & 2.63 & 11.79 \\
Mesopropithecus globiceps & 1.95 & $\mathbf{0 . 0 8}$ & 7.23 \\
Babakotia radofilai & $\mathbf{0 . 1 0}$ & 1.44 & 9.66 \\
Palaeopropithecus kelyus & $\mathbf{1 . 7 0}$ & 2.50 & 11.56 \\
Palaeopropithecus maximus & $\mathbf{0 . 5 5}$ & 1.01 & 8.89 \\
Pachylemur insignis & 4.79 & $\mathbf{1 . 8 0}$ & 3.86 \\
Pachylemur jullyi & 4.85 & $\mathbf{1 . 8 4}$ & 11.21 \\
Megaladapis edwardsi & $\mathbf{1 . 4 1}$ & 2.31 & 13.01 \\
Megaladapis madagascariensis & $\mathbf{2 . 9 3}$ & 3.31 & \\
\hline
\end{tabular}

The smallest distances (suggesting most likely diet) are given in bold. FL = Folivorous; FR = frugivorous; $\mathrm{OM}=$ omnivorous.

\section{Discussion}

This study confirms significant differences in the relative IOF sizes of folivorous and frugivorous lemurs, and further demonstrates a highly significant difference in the relative IOF sizes of frugivorous lemurs supplementing fruit with leaves and those depending more on animals and/or exudates as sources of protein, with the latter group (our 'frugivore-omnivores') exhibiting relatively larger foramina. Malagasy omnivores differ markedly from insectivorous primates outside Madagascar, which tend to have relatively small IOFs [Muchlinski, 2008, 2010a, b]. The critical factor may be the manner in which food is procured, and the importance of facial tactile exploration of foods. Whereas primates in general have relatively small IOFs due to the transfer of touch discrimination from the face to the hands, the primate species with the relatively largest IOFs are the omnivorous lemurs of Madagascar. Among non-primates, facial specializations related to food exploration, and indeed food manipulation, occur in omnivores as well as herbivores. Furthermore, the living omnivorous lemurs are really primarily frugivores that supplement fruit with insects, other arthropods, gums, vertebrates, and/or insect secretions in order to reach their protein quotient; none is a classic visually directed predator of solitary flying insects [Rasmussen and Sussman, 2007].

We hypothesize that, when animals depend on sensory signals from their vibrissae and anterior dentition to explore objects of dietary interest, they tend to have exceptionally large IOFs. Among lemurs, the cheirogaleids and Daubentonia may fit this description. Of particular interest are those species that regularly engage in bark gouging or extractive foraging. Unfortunately, little is known about the role that facial touch sensitivity plays in the feeding ecology of these animals, and experimental research is lacking. 
Table 4. Dietary inferences for subfossil lemurs based on relative IOF size, with comparisons to inferences drawn in prior studies

\begin{tabular}{|c|c|c|c|}
\hline Species & Prior dietary assessments & $\begin{array}{l}\text { Predicted } \\
\text { diet } \\
\text { (this paper) }\end{array}$ & $\begin{array}{l}\text { Probability of } \\
\text { membership } \\
\text { in assigned } \\
\text { group, \% }\end{array}$ \\
\hline $\begin{array}{l}\text { Archaeolemur } \\
\text { edwardsi }\end{array}$ & $\begin{array}{l}\text { - Frugivore, mainly fruit with hard pericarps [Tattersall, 1973, 1982] } \\
\text { - Mainly fruit and seeds, some leaves and fauna [Godfrey et al., 1997] } \\
\text { - Hard object processor, Cebus apella or Daubentonia } \\
\text { madagascariensis-like omnivore [Godfrey et al., 2004, 2005] } \\
\text { - Varied, only facultatively a hard-object feeder [Ravosa, 1991; Rafferty } \\
\text { et al., 2002; Scott et al., 2009] }\end{array}$ & FR-OM & 100 \\
\hline $\begin{array}{l}\text { Archaeolemur } \\
\text { majori }\end{array}$ & $\begin{array}{l}\text { - Frugivore, mainly fruit with hard pericarps [Tattersall, 1973, 1982] } \\
\text { - Mainly fruit and seeds, some leaves and fauna [Godfrey et al., 1997] } \\
\text { - Hard objects, Cebus apella or Daubentonia } \\
\text { - } \text { madagascariensis-like omnivore [Godfrey et al., 2004, 2005] } \\
\text { Varied, only facultatively a hard-object feeder [Ravosa, 1991; Rafferty } \\
\text { et al., 2002; Scott et al., 2009] }\end{array}$ & FR-OM & 100 \\
\hline $\begin{array}{l}\text { Archaeolemur sp. } \\
\text { cf. A. edwardsi }\end{array}$ & $\begin{aligned} \text { - } & \text { Frugivore [Tattersall, 1973] } \\
\text { - } & \text { Mainly fruit and seeds, some leaves and fauna [Godfrey et al., 1997] } \\
\text { - } & \text { Hard object processor, Cebus apella or Daubentonia } \\
& \text { madagascariensis-like omnivore [Godfrey et al., 2004, 2005] } \\
\text { - } & \text { Omnivore, generalist [Burney et al., 1997; Vasey et al., in press] }\end{aligned}$ & FR-OM & 100 \\
\hline $\begin{array}{l}\text { Archaeoindris } \\
\text { fontoynontii }\end{array}$ & - Highly folivorous [Godfrey et al., 1997, 2004] & $\mathrm{FL}$ & 99.6 \\
\hline $\begin{array}{l}\text { Mesopropithecus } \\
\text { globiceps }\end{array}$ & $\begin{array}{l}\text { - Folivore, some fruit and seeds [Godfrey et al., 1997] } \\
\text { - Mixed fruit, seeds, and foliage [Godfrey et al., 2004] }\end{array}$ & FR-FL & 84.6 \\
\hline $\begin{array}{l}\text { Babakotia } \\
\text { radofilai }\end{array}$ & $\begin{aligned} \text { - } & \text { Folivore, some fruit and seeds [Godfrey et al., 1997] } \\
\text { - } & \text { Mixed fruit, seeds, and foliage, some hard objects } \\
& \text { [Rafferty et al., 2002; Godfrey et al., 2004] }\end{aligned}$ & FL & 89.5 \\
\hline $\begin{array}{l}\text { Palaeopropithecus } \\
\text { kelyus }\end{array}$ & - Mixed fruit, seeds, and foliage [Godfrey et al., 2004] & FL & 99.4 \\
\hline $\begin{array}{l}\text { Palaeopropithecus } \\
\text { maximus }\end{array}$ & $\begin{array}{l}\text { - Folivore, some fruit and seeds [Ravosa, 1991; Godfrey et al., 1997; } \\
\text { Rafferty et al., 2002] } \\
\text { - } \text { Mixed fruit, seeds, and foliage [Godfrey et al., 2004] }\end{array}$ & FL & 71.6 \\
\hline $\begin{array}{l}\text { Pachylemur } \\
\text { insignis }\end{array}$ & $\begin{array}{l}\text { - Frugivore, hard fruits [Seligsohn and Szalay, 1974] } \\
\text { - Highly frugivorous [Godfrey et al., 2004] } \\
\text { - Tougher or more obdurate than foods of closest } \\
\text { relatives [Ravosa, 1991, 1992] }\end{array}$ & FR-FL & 81.2 \\
\hline Pachylemur jullyi & - Highly frugivorous [Godfrey et al., 2004] & FR-FL & 75.8 \\
\hline $\begin{array}{l}\text { Megaladapis } \\
\text { edwardsi }\end{array}$ & $\begin{array}{l}\text { - Folivore [Tattersall, 1982; Godfrey et al., 1997; Jungers et al., 2002; } \\
\text { Rafferty et al., 2002; Scott et al., 2009] } \\
\text { - Highly folivorous [Godfrey et al., 2004] }\end{array}$ & $\mathrm{FL}$ & 99.0 \\
\hline $\begin{array}{l}\text { Megaladapis } \\
\text { madagascariensis }\end{array}$ & $\begin{array}{l}\text { - Folivore [Tattersall, 1982; Godfrey et al., 1997; Jungers et al., 2002; } \\
\text { Rafferty et al., 2002; Scott et al., 2009] } \\
\text { - Highly folivorous [Godfrey et al., 2004] }\end{array}$ & $\mathrm{FL}$ & 99.9 \\
\hline
\end{tabular}

$\mathrm{FR}=$ Frugivorous $; \mathrm{OM}=$ omnivorous $; \mathrm{FL}=$ folivorous . 
Nevertheless, some supporting observations exist. Consider the case of Daubentonia, the aye-aye, which has been described as a consumer of 'structurally defended' resources. These animals have unique morphological specializations (an ever-growing anterior dentition, a filiform middle finger and elongated fourth digit used in scraping) to assist in harvesting larvae from dead wood [Sterling, 1993; Lhota et al., 2008]. They use both auditory and olfactory cues to 'mine' for wood-boring lepidopterans and coleopterans [Erickson, 1994; Erickson, et al., 1998], and indeed are unusual among primates in their use of self-generated acoustical cues during foraging [Erikson, 1995]. Given that their targeted foods are often hidden (or 'structurally defended'), visual cues are likely unimportant, but neither can auditory or olfactory cues explain their enlarged IOFs. Indeed, only sensory cues can explain variation in the relative size of the IOF.

In Daubentonia, the upper lip is immobile. However, unlike many primates, including other strepsirhines, Daubentonia has long vibrissae, which are organized in a fashion similar to rodents [Muchlinski, 2010b; S. Lhota, pers. commun.]. While foraging, aye-ayes often position their faces close to the objects being explored (dead or living wood, or fruits with hard exocarps), at such a distance that the long vibrissae come into direct and continual contact with the surface [S. Lhota, pers. commun.]. In so doing, they may be able to use their vibrissae while tapping with their third digits [Lhota et al., 2008] to: (1) interpret reverberations of sound (or echoes) in the air-filled tunnels created by insects; (2) sense vibrations caused by movements of lepidopteran and coleopteran larvae within those tunnels, and perhaps (3) locate the best places to drill into fruits with targeted flesh or kernels. We propose that facial touch sensitivity is critically important to foraging aye-ayes, and that their enlarged IOFs reflect that importance. We further suggest that facial touch sensitivity is important to bark gougers (including exudate feeders) more generally, and to other extractive foragers that use their mouths and anterior teeth as exploratory and preparatory tools.

With regard to the subfossil lemurs, perhaps the most significant finding of our research is that all 3 species of Archaeolemur have relatively large IOFs, contrasting sharply with species at the opposite extreme of the spectrum (M. madagascariensis, A. fontoynontii, P. kelyus, and M. edwardsi). This constitutes independent corroboration of the hypothesis that Archaeolemur was omnivorous while the megaladapids and most of the palaeopropithecids were folivores (table 4). Also supported by our data is the hypothesis that both species of Pachylemur were frugivorous [Godfrey and Irwin, 2007; Crowley et al., 2011]. Of the palaeopropithecids, only Mesopropithecus falls squarely within range of extant lemur frugivores supplementing fruit with foliage. Its relative IOF value is similar to that of $P$. verreauxi, a physiological folivore [Campbell et al., 2000] that sometimes consumes considerable fruit, and that also falls in the middle of the extant lemur frugivore range. Stable carbon isotope data support niche separation for Mesopropithecus and Propithecus, with the former likely consuming more CAM or C4 plants [Crowley et al., 2011]. Nevertheless, relatively high fruit (or seed) consumption is not implausible for Mesopropithecus. Leaves appear to have been the resource favored by most, if not all, other palaeopropithecids and all megaladapids examined here. Interestingly, the giant lemurs found to be most extreme in terms of having the relatively smallest IOFs (Megaladapis and Archaeoindris) match perfectly those taxa found to have dental topographic features ('complexity' and 'Dirichlet normal energy', a metric being developed for dental surface 
analysis by Jonathan Bunn and colleagues) most like those of extant lemurs specializing on tree foliage (Lepilemur and Avahi), while Archaeolemur resembles Daubentonia in its dental topographic complexity and Dirichlet normal energy measurements [Godfrey et al., 2010; Bunn et al., in press; see also Evans et al., 2007, for an explanation of 'complexity' or 'orientation patch count' measurements].

\section{Acknowledgments}

For access to specimens, we would like to thank the curators at the Académie Malgache, the American Museum of Natural History, the Field Museum of Natural History, Duke Lemur Center, and the University of Antananarivo (Laboratoire de Paléontologie des Vertébrés). Stan Lhota provided invaluable unpublished observations. We thank Seth Dobson for helpful discussions about phylogenetic methods. This research was supported by a Field Museum Visiting Scholar Award (M.N.M.); NSF - MU-ADVANCE 0929997 (M.N.M.) and support from the John Simon Guggenheim Foundation (L.R.G.), American Philosophical Society Franklin Research Grant (K.M.M.) and the Claire Garber Goodman Fund, Dartmouth College (K.M.M.).

\section{References}

Ahl AS (1986). The role of vibrissae in behavior. Veterinary Research Communication 10: 245-268.

Ahl AS (1987). Relationship of vibrissal length and habits in the Sciuridae. Journal of Mammalogy 68: $848-853$.

Andrews JR, Birkinshaw CR (1998). A comparison between the daytime and night-time diet, activity and feeding height of the black lemur, Eulemur macaco (Primates: Lemuridae), in Lokobe Forest, Madagascar. Folia Primatologica 69(suppl 1): 175-182.

Balko E (1998). A Behaviorally Plastic Response to Forest Composition and Logging Disturbance by Varecia variegata variegata in Ranomafana National Park, Madagascar. PhD dissertation, State University of New York, Syracuse.

Baron G, Stephan H, Frahm H (1990). Comparison of brain structure volumes in Insectivora and Primates, IX Trigeminal Complex. Journal für Hirnforschung 31: 193-200.

Birkinshaw CR, Colquhoun IC (1998). Pollination of Ravenala madagascariensis and Parkia madagascariensis by Eulemur macaco in Madagascar. Folia Primatologica 69: 252-259.

Brecht M, Preilowski B, Merzenich M (1997). Functional architecture of the mystacial vibrissae. Behavioral and Brain Research 84: 81-97.

Bunn JM, Boyer DM, Lipman Y, St. Clair EM, Jernvall J, Daubechies I (in press). Comparing Dirichlet normal surface energy of tooth crowns, a new technique of molar shape quantification for dietary inference, with previous methods in isolation and in combination. American Journal of Physical Anthropology.

Burney DA, James HF, Grady FV, Rafamantanantsoa JG, Ramilisonina, Wright HT, Cowart JB (1997). Environmental change, extinction and human activity: evidence from caves in NW Madagascar. Journal of Biogeography 24: 755-767.

Campbell JL, Eisemann JH, Williams CV, Glenn KM (2000). Description of the gastrointestinal tract of five lemur species: Propithecus tattersalli, Propithecus verreauxi coquereli, Varecia variegata, Hapalemur griseus, and Lemur catta. American Journal of Primatology 52: 133-142.

Colquhoun I (1997). A Predictive Socioecology Study of the Black Lemur (Eulemur macaco macaco) in Northwestern Madagascar. PhD dissertation, Washington University, St. Louis.

Crowley BE, Godfrey LR, Irwin MT (2011). A glance to the past: subfossils, stable isotopes, seed dispersal, and lemur species loss in southern Madagascar. American Journal of Primatology 73: 25-37.

Cull G, Cioffi G, Dong J, Homer L, Wang L (2003). Estimating normal optic nerve axon numbers in non-human primate eyes. Journal of Glaucoma 12: 301-306.

Dammhahn M, Kappeler PM (2008). Comparative feeding ecology of sympatric Microcebus berthae and Microcebus murinus. International Journal of Primatology 29: 1567-1589.

Dominy NJ (2004). Fruits, fingers, and fermentation: the sensory cues available to foraging primates. Integrative and Comparative Biology 44: 29-37. 
Dominy NJ, Lucas PW, Osorio D, Yamashita N (2001). The sensory ecology of primate food preception. Evolutionary Anthropology 10: 171-186.

-Ebara S, Kumamoto, K, Matsuura T, Mazurkiewicz J, Rice F (2002). Similarities and differences in the innervation of mystacial vibrissal follicle-sinus complexes in the rat and cat, a confocal microscopic study. Journal of Comparative Neurobiology 449: 103-119.

Erickson CJ (1994). Tap-scanning and extractive foraging in aye-ayes, Daubentonia madagascariensis. Folia Primatologica 62: 125-135.

Erickson CJ (1995). Feeding sites for extractive foraging by the aye-aye, Daubentonia madagascariensis. American Journal of Primatology 35: 235-240.

Erickson CJ, Nowicki S, Dollar L, Goehring N (1998). Percussive foraging: stimuli for prey location by aye-ayes (Daubentonia madagascariensis). International Journal of Primatology 19: 111-122.

Evans A, Wilson G, Fortelius M, Jernvall J (2007). High-level similarity of dentitions in carnivorans and rodents. Nature 445: 78-81.

Faulkner AL, Lehman SM (2006). Feeding patterns in a small-bodied nocturnal folivore (Avahi laniger) and the influence of leaf chemistry: a preliminary study. Folia Primatologica 77: 218-227.

Fietz J, Ganzhorn J (1999). Feeding ecology of the hibernating primate Cheirogaleus medius: how does it get so fat? Oecologia 121: 157-164.

Fisher RA (1925). Statistical Methods for Research Workers. New York, Hafner Publishing Co. Inc.

-Ganzhorn JU, Abraham J-P, Razanahoera-Rakotomalala M (1985). Some aspects of the natural history and food selection of Avahi laniger. Primates 26: 452-463.

-Ganzhorn JU, Arrigo-Nelson S, Boinski S, Bollen A, Carrai V, Derby A, Donati G, Koenig A, Kowalewski M, Lahann P, Norscia I, Polowinsky SY, Schwitzer C, Stevenson PR, Talebi MG, Tan C, Vogel ER, Wright PC (2009). Possible fruit protein effects on primate communities in Madagascar and the Neotropics. PLoS ONE 4: e8253.

Garland T Jr, Midford P, Ives A (1999). An introduction to phylogenetically based statistical methods with a new method for confidence intervals and ancestral values. American Zoologist 39: 374-388.

Gerson J (2000). Social Relationships in Wild Red-Fronted Brown Lemurs (Eulemur fulvus rufus). PhD dissertation, Duke University, Durham.

Godfrey LR, Irwin MT (2007). The evolution of extinction risk: past and present anthropogenic impacts on the primate communities of Madagascar. Folia Primatologica 78: 405-419.

Godfrey LR, Jungers WL, Reed KE, Simons EL, Chatrath PS (1997). Subfossil lemurs: inferences about past and present primate communities. In Natural Change and Human Impact in Madagascar (Goodman SM, Patterson B, eds.), pp 218-256. Washington, Smithsonian Institution Press.

Godfrey LR, King SJ, Muldoon KM, Blanco MB (2010). Dental complexity, topographic relief, and dietary reconstruction in subfossil lemurs. American Journal of Physical Anthropology 50: 111-112.

Godfrey LR, Semprebon GM, Jungers WL, Sutherland MR, Simons EL, Solounias N (2004). Dental use wear in extinct lemurs: evidence of diet and niche differentiation. Journal of Human Evolution 47: $145-169$.

Godfrey LR, Semprebon GM, Schwartz GT, Burney DA, Jungers WL, Flanagan EK, Cuozzo FP, King SJ (2005). New insights into old lemurs: the trophic adaptations of the Archaeolemuridae. International Journal of Primatology 26: 825-854.

Grassi C (2006). Variability in habitat, diet, and social structure of Hapalemur griseus in Ranomafana National Park, Madagascar. American Journal of Physical Anthropology 131: 50-63.

-Harcourt C (1991). Diet and behaviour of a nocturnal lemur, Avahi laniger, in the wild. Journal of Zoology, London 223:667-674.

Hemingway CA (1998). Selectivity and variability in the diet of Milne-Edwards' Sifakas (Propithecus diadema edwardsi): implications for folivory and seed-eating. International Journal of Primatology 19: 355-377.

Hladik CM, Charles-Dominique P, Petter JJ (1980). Feeding strategies of five nocturnal prosimians in the dry forest of the west coast of Madagascar. In Nocturnal Malagasy Primates (Charles-Dominique P, Cooper HM, Hladik A, Hladik CM, Pages E, Pariente GF, Petter-Rousseaux A, Shilling A, eds.) pp 41-73. New York, Academic Press.

Horvath JE, Weisrock DW, Embry SL, Fiorentino I, Balhoff JP, Kappeler P, Wray GA, Willard HF, Yoder AD (2008). Development and application of a phylogenomic toolkit: resolving the evolutionary history of Madagascar's lemurs. Genome Research 18: 489-499.

Hylander WL (1985). Mandibular function and biomechanical stress and scaling. American Zoologist 25:315-330.

Jonas J, Schmidt A, Müller-Bergh J, Schlötzer-Schrehardt U, Naumann O (1992). Human optic nerve fiber count and optic disc size. Investigative Ophthalmology Vision Science 33: 2012-2018.

Jungers WL (1990). Problems and methods in reconstructing body size in fossil primates. In Body Size in Mammalian Paleobiology (Damuth J, MacFadden BJ, eds.), pp 103-118. Cambridge, Cambridge University Press. 
Jungers WL, Demes B, Godfrey LR (2008). How big were the 'giant' extinct lemurs of Madagascar? In Elwyn Simons: A Search for Origins (Fleagle JG, Gilbert CC, eds.), pp 343-360. New York, Springer.

Jungers WL, Godfrey LR, Simons EL, Wunderlich RE, Richmond BG, Chatrath PS (2002). Ecomorphology and behavior of giant extinct lemurs from Madagascar. In Reconstructing Behavior in the Primate Fossil Record (Plavcan JM, Kay RF, Jungers WL, van Schaik C, eds.), pp 371-411. New York, Kluwer Academic/Plenum Publishers.

Kandel E, Schwartz J, Jessell T (2000). Principles of Neural Science. New York, McGraw-Hill.

Kay RF (1973). Mastication, molar tooth structure, and diet in primates. PhD dissertation Yale University, New Haven.

Klages M, Muyakshin S, Soltwedel T, Arntz WE (2002). Mechanoreception, a possible mechanism for food fall detection in deep-sea scavengers. Deep Sea Research 49: 143-155.

Lahann P (2007). Feeding ecology and seed dispersal of sympatric cheirogaleid lemurs (Microcebus murinus, Cheirogaleus medius, Cheirogaleus major) in the littoral rainforest of south-east Madagascar. Journal of Zoology 271: 88-98.

Lehman SM (2007). Spatial variation in Eulemur fulvus rufus and Lepilemur mustelinus densities in Madagascar. Folia Primatologica 78: 46-55.

Lhota S, Junek T, Bartos L, Kubena AA (2008). Specialized use of two fingers in free-ranging aye-ayes. American Journal of Primatology 70: 786-795.

Lucas PW (1994). Categorisation of food items relevant to oral processing. In The Digestive System in Mammals: Food, Form, and Function (Chivers D, Langer P eds.), pp 197-219. Cambridge, Cambridge University Press.

Mackinnon S, Dellon A 1995. Fascicular patterns of the hypoglossal nerve. Journal of Reconstructive Microsurgery 11: 195-198.

Maddison W, Maddison D (2007). Mesquite: A Modular System for Evolutionary Analysis, Version 2.01. http://mesquiteproject.org.

Marino L (2007). Cetacean brains: how aquatic are they? Anatomical Record 290: 694-700.

Marshall CD, Amin H, Kovacs KM, Lydersen C (2006). Microstructure and innervation of the mystacial vibrissal follicle-sinus complex in bearded seals, Erignathus barbatus (Pinnipedia, Phocidae). Anatomical Record 288A: 13-25.

Midford PE, Garland T Jr, Maddison WP (2009). PDAP Package for Mesquite. Version 2.72.

Morland H (1992). Social Organization and Ecology of Black and White Ruffed Lemurs (Varecia variegata variegata) in Lowland Rain Forest, Nosy Mangabe, Madagascar. PhD dissertation, Yale University, New Haven.

Muchlinski MN (2002). Anatomical Correlates to Nectar Feeding among the Strepsirhines of Madagascar. Masters Thesis, University of Texas at Austin.

Muchlinski MN (2008). The infraorbital foramen, infraorbital nerve, and maxillary mechanoreception: implications of interpreting the paleoecology of fossil mammals based on infraorbital foramen size. Anatomical Record 291: 1221-1226.

Muchlinski MN (2010a). A comparative analysis of vibrissa count and infraorbital foramen area in primates and other mammals. Journal of Human Evolution 58: 447-473.

Muchlinski MN (2010b). Ecological correlates of infraorbital foramen size in primates. American Journal of Physical Anthropology 141: 131-141.

Muldoon KM, Goodman SM (2010). Ecological biogeography of Malagasy non-volant mammals: community structure is correlated with habitat. Journal of Biogeography 37: 1144-1159.

Oelschlager HA, Oelschlager JSO (2002). Brain. In Encyclopedia of Marine Mammals (Perrin WF, Wursig B, Thewissen JGM, eds.), pp 133-158. San Diego, Academic Press.

Orlando L, Calvignac S, Schnebelen C, Douady CJ, Godfrey LR, Hänni C (2008). DNA from extinct giant lemurs links archaeolemurids to extant indriids. BMC Evolutionary Biology DOI: $10.1186 / 1471-$ 2148-8-121.

Overdorff DJ (1996). Ecological correlates to social structure in two lemur species in Madagascar. American Journal of Physical Anthropology 100: 487-506.

Pages E (1980). Ethoecology of Microcebus coquereli during the dry season. In Nocturnal Malagasy Primates (Charles-Dominique P, Cooper HM, Hladik A, Hladik CM, Pages E, Pariente GF, PetterRousseaux A, Shilling A, eds.), pp 97-116. New York, Academic Press.

Peleg M (1980). A note on the sensitivity of fingers, tongue and jaws as mechanical testing instruments. Journal of Textile Studies 10: 245-251.

Powzyk J (1998). The Socio-Ecology of Two Sympatric Indrids, Propithecus diadema diadema and Indri indri: A Comparison of Feeding Strategies and Their Possible Repercussions on Species-Specific Behaviors. PhD dissertation, Duke University, Durham.

Radespiel U, Reimann W, Rahelinirina M, Zimmermann E (2006). Feeding ecology of sympatric mouse lemur species in northwestern Madagascar. International Journal of Primatology 27: 311-321. 
Rafferty KL, Teaford MF, Jungers WL (2002). Molar microwear of subfossil lemurs: improving the resolution of dietary inferences. Journal of Human Evolution 43: 645-657.

Rasmussen DT, Sussman RW (2007). Parallelisms among primates and possums. In Primate Origins: Adaptations and Evolution (Ravosa M, Dagosto M, eds.), pp 775-804. New York, Springer.

Ratsimbazafy JH (2002). On the Brink of Extinction and the Process of Recovery: Responses of Black and White Ruffed Lemurs (Varecia variegata variegata) to Disturbance in Manombo Forest, Madagascar. PhD dissertation, SUNY Stony Brook, New York.

Ravosa M (1991). Structural allometry of the prosimian mandibular corpus and symphysis. Journal of Human Evolution 20: 3-20.

Ravosa MJ (1992). Allometry and heterochrony in extant and extinct Malagasy primates. Journal of Human Evolution 23: 197-217.

Richard AF (1974). Intra-specific variation in the social organization and ecology of Propithecus verreauxi. Folia Primatologica 22: 178-207.

Richard AF (1978). Variability in feeding behavior of a Malagasy prosimian, Propithecus verreauxi: Lemuriformes. In The Ecology of Arboreal Folivores (Montgomery G, ed.), pp 519-533. Washington, Smithsonian Institution Press.

Richard AF (1987). Malagasy prosimians: female dominance. In Primate Societies (Smuts BB, Cheney DL, Seyfarth RM, Wrangham RW, Struhsaker TT, eds.), pp 25-33. Chicago, University of Chicago Press.

- Sailer LD, Gaulin SJ, Boster JS, Kurland JA (1985). Measuring the relationship between dietary quality and body size in primates. Primates 26: 14-27.

- Sauther M (1991). Reproductive behavior of free-ranging Lemur catta at Beza Mahafaly Special Reserve, Madagascar. American Journal of Physical Anthropology 84: 463-477.

- Scott JR, Ungar PS, Jungers WL, Godfrey LR, Scott RS, Simons EL, Teaford MF, Walker A (2009). Dental microwear texture analysis of two genera of subfossil lemurs from Madagascar. Journal of Human Evolution 56: 405-416.

Seligsohn D, Szalay FS (1974). Dental occlusion and the masticatory apparatus in Lemur and Varecia: their bearing on the systematics of living and fossil primates. In Prosimian Biology (Martin RD, Doyle GA, Walker AC, eds.), pp 543-561. London, Duckworth.

Simmen B, Hladik A, Ramasiarisoa P (2003). Food intake and dietary overlap in native Lemur catta and Propithecus verreauxi and introduced Eulemur fulvus at Berenty, southern Madagascar. International Journal of Primatology 24: 948-967.

Sterling EJ (1993). Patterns of range use and social organization in aye-ayes (Daubentonia madagascariensis) on Nosy Mangabe. In Lemur Social Systems and their Ecological Basis (Kappeler PM, Ganzhorn JU, eds.), pp 1-10. New York, Plenum Press.

Sterling EJ (1994). Aye-ayes - Specialists on structurally defended resources. Folia Primatologica 62 : 142-154.

Sussman RW (1974). Ecological distinctions in sympatric species of lemur. In Prosimian Biology (Martin RD, Doyle GA, Walker AC, eds.), pp 75-108. London, Duckworth.

- Tattersall I (1973). Cranial anatomy of Archaeolemurinae (Lemuroidea, Primates). Anthropological Papers of the American Museum of Natural History 52: 1-110.

Tattersall I (1982). The Primates of Madagascar. New York: Columbia University Press.

Tecot S (2008). Seasonality and Predictability: The Hormonal and Behavioral Responses of the Red-Bellied Lemur, Eulemur rubriventer, in Southeastern Madagascar. PhD dissertation, University of Texas, Austin.

-Ungar P (1998). Dental allometry, morphology, and wear as evidence for diet in fossil primates. Evolutionary Anthropology 6: 205-217.

Ungar P (2002). Reconstruting the diets of fossil primates. In Reconstructing Behavior in the Primate Fossil Record (Plavcan MJ, Kay RF, Jungers WL, van Schaik C, eds.), pp 261-296. New York, Kluwer Academic Plenum Publishers.

Vasey N (2000). Niche separation in Varecia variegata rubra and Eulemur fulvus albifrons. 1. Interspecific patterns. American Journal of Physical Anthropology 112: 411-431.

Vasey N, Burney DA, Godfrey LR (in press). Archaeolemur coprolites from Anjohikely Cave in Northwestern Madagascar reveal dietary diversity and cave use in a subfossil prosimian. In Leaping Ahead: Advances in Prosimian Biology (Masters J, Gamba M, Génin F, eds.). New York, Springer.

Wright PC, Martin LB (1995). Predation, pollination and torpor in two nocturnal prosimians: Cheirogaleus major and Microcebus rufus in the rain forest of Madagascar. In Creatures of the Dark: The Nocturnal Prosimians (Alterman L, Doyle GA, Izard MK, eds.), pp 45-60. New York, Plenum Press.

Yamashita N (2002). Diets of two lemur species in different microhabitats in Beza Mahafaly Special Reserve, Madagascar. International Journal of Primatology 23: 1025-1051.

Subfossil Lemur Diets and Infraorbital Foramen Size
Folia Primatol 2010;81:330-345 